\title{
Does Thyroid-Stimulating Hormone Influence the Prognosis of Patients with Renal Cell Carcinoma?
}

\author{
Mustafa Karaca $^{1 *}$, Mehmet Celik ${ }^{2}$, Mehmet Ilker Turan ${ }^{3}$ and Sema Erturk ${ }^{1}$ \\ ${ }^{1}$ Health Sciences University Medical Faculty, Antalya Training and Research Hospital, Medical Oncology, Turkey \\ ${ }^{2}$ Antalya Kepez State Hospital, Department of Endocrinology and Metabolism, Turkey
}

${ }^{3}$ Antalya Kepez State Hospital, Department of General Surgery, Turkey

*Corresponding author: Mustafa Karaca, Health Sciences University Medical Faculty, Antalya Training and Research Hospital,

Medical Oncology, Antalya, Turkey

\section{ARTICLE INFO}

Received: 幽 August 21, 2019

Published: 蔧 August 27, 2019

Citation: Mustafa K, Mehmet C, Mehmet Ilker T, Sema E. Does ThyroidStimulating Hormone Influence the Prognosis of Patients with Renal Cell Carcinoma?. Biomed J Sci \& Tech Res 20(5)-2019. BJSTR. MS.ID.003522.

Keywords: Renal Cell Carcinoma; ThyroidStimulating Hormone; Prognostic Parameter

\section{ABSTRACT}

Objective: Thyroid function has been suggested to affect tumor pathophysiology and prognosis in various cancers. In this study, we aimed to investigate the effect of pretreatment serum thyroid-stimulating hormone (TSH) levels on the prognosis of renal cell cancer patients.

Methods: We retrospectively investigated serum TSH in 125 patients with renal cell carcinoma. After exclusion criteria were applied, 40 patients were included in the study. TSH levels were analyzed on survival in patients with renal cell cancer. According to TSH levels, patients were evaluated in two groups: TSH $\leq 2.5 \mathrm{mU} / \mathrm{L}$ (normal low) and TSH> $2.5 \mathrm{mU} / \mathrm{L}$ (elevated).

Results: Survival analysis was not associated with disease-specific survival in both normal low TSH and elevated TSH groups before treatment (p: 0.274).

Conclusion: Pre-treatment thyroid-stimulating hormone was not a prognostic parameter for disease-specific survival in patients with renal cell cancer. In this respect, prospective studies including more patients are needed.

Abbreviations: TNM: Tumor, Node, Metastasis; RCC: Renal Cell Cancer; PFS: ProgressionFree Survival; OS: Overall Survival

\section{Introduction}

The thyroid gland is vital for the metabolic activity and function of most organ systems in living organisms. In the literature, it has been argued that there is a possible interaction between thyroid function and prognosis in different cancers [1-3]. Hypothyroidism is rarely caused by any disorder in the hypotonus-pituitarythyroid axis, and approximately $99 \%$ of the cases are caused by the thyroid gland disease. The incidence of hypothyroidism is annual; it is given as 3.5 per 1000 in women and 0.6 per 1000 in men. Hypothyroidism is seen 5 -8 times more in women than in men $[4,5]$. Previous studies have clearly demonstrated that one of the known known side effects of tyrosine kinase inhibitors used in patients with renal cell cancer is abnormal thyroid function $[6,7]$. Wolter et al. [8] reported that patients with thyroid dysfunction taking sunitinib had longer progression-free survival than patients without these abnormalities. In our study, we aimed to investigate the relationship between pretreatment TSH levels and prognosis.

\section{Materials and Methods}

In this study, the files of 125 renal cell carcinomas diagnosed between 2006 and 2016 were evaluated retrospectively. Patients with chronic systemic diseases and other malignant conditions that could affect the prognosis of the patients were excluded from the study. Patients with hypertension, diabetes mellitus, chronic ischemic heart disease, cerebrovascular disease, chronic obstructive pulmonary disease and chronic renal failure were excluded. After exclusion criteria were applied, 40 patients were included in the study. Clinical, laboratory and histopathological results and final status of the patients were recorded. Eighth (2017) 
Tumor, Node, Metastasis (TNM) staging system was used to identify prognostic stage groups. This system is supported by the American Joint Cancer Joint Committee (AJCC) and the International Cancer Control Association (UICC) [9]. TSH measurement: Pre-treatment serum values were used. According to the National Academy of Clinical Biochemistry recommendation, TSH serum level was accepted as the normal upper limit of $2.5 \mathrm{mU} / \mathrm{L}$ [10] According to TSH levels, patients were evaluated in two groups: TSH $\leq 2.5 \mathrm{mU} / \mathrm{L}$ (normal low) and TSH> $2.5 \mathrm{mU} / \mathrm{L}$ (elevated).

\section{Statistical Analysis}

We used the statistical software SPSS 22.0 for Windows (IBM SPSS Statistics 22.0.0, Armonk, NY: IBM Corp.) for statistical analysis. Values are given as number or median as appropriate. Kruskal-Wallis one-way analysis of variance was used to assess the association between serum TSH and clinical- histopathological parameters. For survival analysis, patients were assigned to two prognostic groups. Survival probabilities were calculated by the product limit method of Kaplan and Meier. The P-values of $<0.05$ were considered statistically significant.

\section{Results}

The clinical and histopathological features of 39 patients receiving tyrosine kinase inhibitor sunitinib and 1 patient receiving pazopanib were evaluated. The mean age of the patients was 56.08 \pm 11.2 years. 30 patients were males and 10 were females. All patients were in stage III and IV groups according to TNM staging. The number of patients with $\mathrm{TSH} \leq 2.5 \mathrm{miU} / \mathrm{L}$ was 30 (75\%) while the number of patients with TSH> $2.5 \mathrm{miU} / \mathrm{L}$ was 10 (25\%). The mean follow-up period of the patients was $36.6 \pm 43.2$ (Table 1). Kaplan - Meier curves analysis was performed to evaluate the effect of TSH level on prognosis. Survival analysis was not associated with disease-specific survival in both normal low TSH and elevated TSH groups before treatment (p: 0.274) (Figure 1) \& (Table 1).

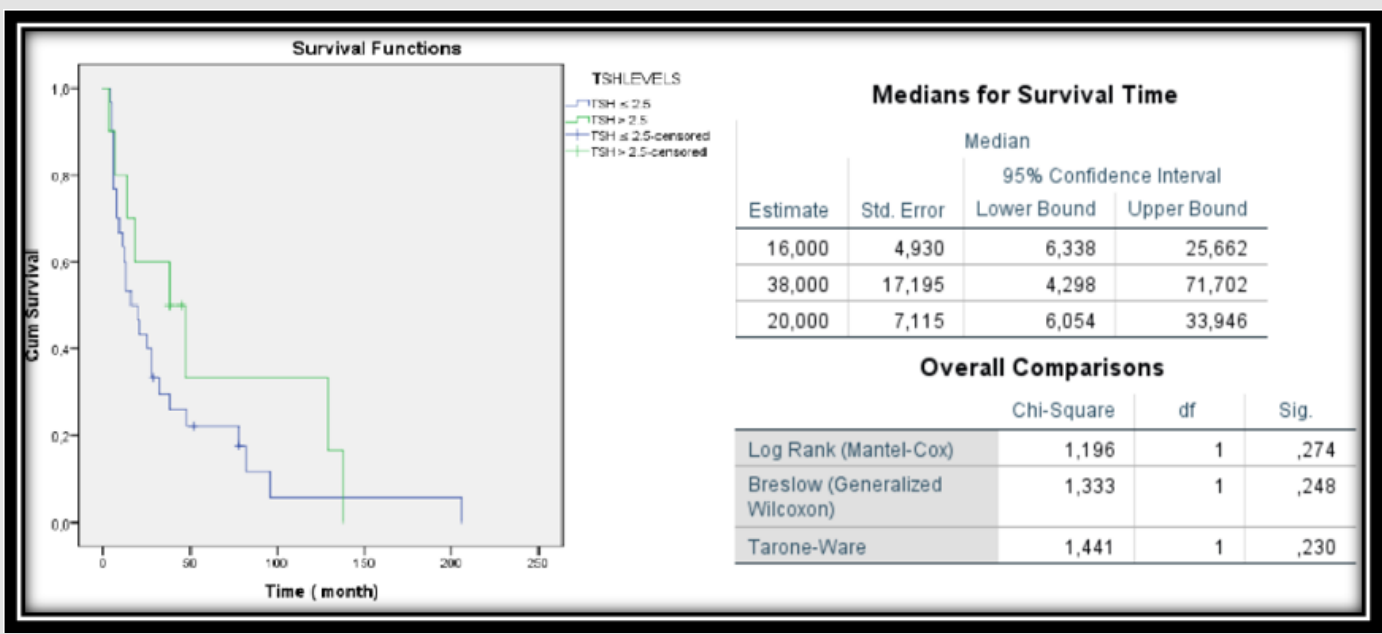

Figure 1: Kaplan-Meier curves for pre-therapeutic TSH risk groups "normal low" (lower line) vs "elevated" (upper line) and patients with renal cell carcinoma survival.

Table 1: Clinical characteristics of patients.

\begin{tabular}{|c|c|c|}
\hline \multicolumn{2}{|c|}{ Age (mean \pm SD, year) } & $56.08 \pm 11.2$ \\
\hline \multicolumn{2}{|c|}{ Gender (Female/male) } & $10(25 \%) / 30(75 \%)$ \\
\hline \multirow{3}{*}{ ECOG Performance status } & Status 0 & $10(25 \%)$ \\
\cline { 2 - 3 } & Status $12.5 \%)$ \\
\cline { 2 - 3 } & Status $~$ & $1(2.5 \%)$ \\
\hline \multirow{3}{*}{ Number of sites with metastasis } & 1 & $19(47.5 \%)$ \\
\cline { 2 - 3 } & 2 & $15(37.5 \%)$ \\
\cline { 2 - 3 } & 3 & $5(12.5 \%)$ \\
\hline Site of Metastasis & 4 & $1(2.5 \%)$ \\
\hline & Lymph node & $3(7.5 \%)$ \\
\hline & Lung & $20(50 \%)$ \\
\hline \multirow{2}{*}{ TSH levels } & Brain & $5(12.5 \%)$ \\
\hline
\end{tabular}




\begin{tabular}{|c|c|c|}
\hline \multirow{2}{*}{ TNM stage } & Stage I & $0(0 \%)$ \\
\cline { 2 - 3 } & Stage II & $0(0 \%)$ \\
\cline { 2 - 3 } & Stage III & $3(7.5 \%)$ \\
\cline { 2 - 3 } & Stage IV & $37(92.5 \%)$ \\
\hline \multirow{2}{*}{ Histology } & Clear cell & $3(7.5 \%)$ \\
\cline { 2 - 3 } & Non-clear cell & $35(87.5 \%)$ \\
\hline \multirow{2}{*}{ Patients' Status } & Exitus (Renal cell cancer) & $1(2.5 \%)$ \\
\cline { 2 - 3 } & Died of other disease & $4(10 \%)$ \\
\hline \multicolumn{2}{|c|}{ Follow up period (mean, \pm SD, month) } & $36.6 \pm 43.2$ \\
\hline
\end{tabular}

\section{Discussion}

Thyroid hormones (mainly T4) promote tumour growth through the stimulation of paracrine growth factors such as epidermal growth factor and insulin-like growth factor [11]. This side effect is not expected in patients with hypothyroidism due to low T3 and T4 levels. The impact of hypothyroidism has been correlated with better outcome in many malignant diseases such as breast carcinoma, head and neck cancer and gliomas $[3,11,12]$. In addition, hypothyroidism has been shown to be associated with a lower incidence and less aggressive breast cancer [3]. In previous studies reported that hypothyroidism improves overall survival in renal cell cancer (RCC) $[10,13]$. Wolter et al. reported that patients with thyroid dysfunction appeared with both longer median progression-free survival (PFS) (10.3 vs. 3.6 months) and overall survival (OS) (18.2 vs. 6.6 months) than the respective PFS and OS of patients who remained euthyroid under their treatment [8].

In another study, hypothyroidism during treatment with sunitinib, tyrosine kinase inhibitor, was a predictive marker of therapeutic efficacy, a significant improvement in overall survival for patients with hypothyroidism [14]. The normal range for TSH is $0.4 \mathrm{mU} / \mathrm{L}$ to $4.0 \mathrm{mU} / \mathrm{L}$. This range may be lower in pregnant women and higher in older people. Clinical hypothyroidism is defined as low serum FT4 or together with elevated TSH. The management of hypothyroidism is well defined in general population, but it is unclear in cancer patients (14). The aim of the thyroid replacement is to provide a TSH serum concentration between 0.50 and 2.50 $\mathrm{mU} / \mathrm{L}$ in patients with hypothyroidism [15]. In our study, we compared the groups of patients with tsh values below 2.5 and above in terms of overall survival, and there was no significant with respect to these differences between the groups ( $p>0.05)$.

\section{Conclusion}

In conclusion, pre-treatment thyroid-stimulating hormone was not a prognostic parameter for disease-specific survival in patients with renal cell cancer. In this respect, prospective studies including more patients are needed.

\section{References}

1. Hercbergs AA, Goyal LK, Suh JH, Lee S, Reddy CA, et al. (2003) Propylthiouracil-induced chemical hypothyroidism with high-dose tamoxifen prolongs survival in recurrent high grade glioma: a phase I/II study. Anticancer Res 23(1B): 617-626.

2. Cristofanilli M, Yamamura Y, Kau SW, Bevers T, Strom S, et al. (2005) Thyroid hormone and breast carcinoma. Primary hypothyroidism is associated with a reduced incidence of primary breast cancer. Cancer 103(6): 1122-1128.

3. Creasman WT, Odicino F, Maisonneuve P, Quinn MA, Beller U, et al. (2006) Carcinoma of the corpus uteri. FIGO 26th annual report on the results of treatment in gynecologic cancer. Int J Gynaecol Obstet 95(S1): 105-143.

4. Aoki Y, Belin RM, Clickner R, Jeffries R, Phillips L, et al. (2007) Serum TSH and total T4 in the United States population and their association with participant characteristics: National Health and Nutrition Examination Survey (NHANES 1999-2002). Thyroid 17(12): 1211-1223.

5. Vanderpump MP, Tunbridge WM (2002) Epidemiology and prevention of clinical and subclinical hypothyroidism. Thyroid 12(10): 839-847.

6. Tamaskar I, Bukowski R, Elson P, Ioachimescu AG, Wood L, et al. (2008) Thyroid function test abnormalities in patients with metastatic renal cell carcinoma treated with sorafenib. Ann Oncol 19(12): 265-268.

7. Rini BI, Tamaskar I, Shaheen P, Salas R, Garcia J, et al. (2007) Hypothyroidism in patients with metastatic renal cell carcinoma treated with sunitinib. J Natl Cancer Inst 99(1): 81-83.

8. Wolter P, Stefan C, Decallonne B, H Dumez, M Bex, et al. (2008) The clinical implications of sunitinib-induced hypothyroidism: a prospective evaluation. Br J Cancer 99(3): 448-454.

9. Rini BI, McKiernan JM, Chang SS (2017) Kidney. In: AJCC Cancer Staging Manual, $8^{\text {th }}$, Amin MB (Ed.), Springer, New York p.739.

10. Baloch Z, Carayon P, Conte Devoix B, Demers LM, Feldt Rasmussen U, et al. (2003) Laboratory medicine practice guidelines. Laboratory support for the diagnosis and monitoring of thyroid disease. Thyroid 13: 3-126.

11. Hercbergs AA, Goyal LK, Suh JH, Lee S, Reddy CA, et al. (2003) Propylthiouracil-induced chemical hypothyroidism with high-dose tamoxifen prolongs survival in recurrent high grade glioma: a phase I/II study. Anticancer Res 23(1B): 617-626.

12. Nelson M, Hercbergs A, Rybicki L, Strome M (2006) Association between development of hypothyroidism and improved survival in patients with head and neck cancer. Arch Otolaryngol Head Neck Surg 132(10): 10411046.

13. Schmidinger M, Vogl UM, Bojic M, Lamm W, Heinzl H, et al. (2011) Hypothyroidism in patients with renal cell carcinoma: blessing or curse? Cancer 117(3): 534-544.

14. Jonklaas, Bianco, Andrew J Bauer, Kenneth D Burman, et al., (2014) Guidelines for the Treatment of Hypothyroidism: Prepared by the American Thyroid Association Task Force on Thyroid Hormone Replacement. Thyroid 24(12): 1670-1751.

15. Vasileiadis T, Chrisofos M, Safioleas M, Kontzoglou K, Papazisis K, et al. (2019) Impact of sunitinib-induced hypothyroidism on survival of patients with metastatic renal cancer. BMC Cancer 19(1): 407. 
ISSN: 2574-1241

DOI: $10.26717 /$ BJSTR.2019.20.003522

Mustafa Karaca. Biomed J Sci \& Tech Res

(C) 7 This work is licensed under Creative Commons Attribution 4.0 License

Submission Link: https://biomedres.us/submit-manuscript.php

$\begin{array}{ll}\text { BIOMEDICAL } & \text { Assets of Publishing with us } \\ \text { RESEARCHES } & \text { - Global archiving of articles } \\ & \text { - Immediate, unrestricted online access } \\ & \text { - Rigorous Peer Review Process } \\ \end{array}$

